表 1 衣料縫製業の実態

\section{縫製企業における}

技術開発のあり方 ${ }^{*}$

\title{
I． 縫製品製造業の実態
}

表 1，2 に我国縫製業の実態を示してあるが，取り扱 い品種は, 紳士服, 婦人服, 子供服, 学生服, スポーツ 服，肌着，ワイジャツ，ブラウス等衣料全般にわたって いる。

企業数は約 25000 社, 労働者数は 41 万人（1企業 当り平均 16.5 人)， 47 年度出荷額は約 1 兆 2400 億円であった。

また，縫製業の主要生産設備は工業用各種ミシン，裁 断機，仕上機などで，資本装備率は 1 人当り数十万円以 下で極めて低く、典型的な労働集約型産業である．企業 数、労働者数，販売金額等の面からみて種々の問題点を 抱之ながらも年々伸長している産業であるが，基本的に は生産性が低く，韓国，台湾，シンガポール等の発展途 上国の追い上げに悩まされており，このまま推移すれば， 我国縫製業の海外市場喪失はおろか，国内市場にも大き な影響を与えることになろう。近年とくに若年労働力需 給のひっ迫が目立っている。

* How to Develop the Technology in Sewing Industry.

**T. Kawakami, Member, 工業技術院 製品科学研究所 所長

\begin{tabular}{|c|c|c|c|}
\hline 項 目 & 47 & 年 & 度 \\
\hline 事 業 所 数 & 29846 & & \\
\hline 従業員 数 & 413 (千人) & & \\
\hline 輸 入 額 & 12 539百万円 & & 49 737午万円 \\
\hline 輸 出 額 & $39702 \quad "$ & & 33529 偖方円 \\
\hline $\begin{array}{l}\text { 出 荷 額 } \\
\text { (内 訳) }\end{array}$ & 124277 & & \\
\hline 5 人以下 & 96936 百万円 & & $(7.8 \%)$ \\
\hline $6 \sim 9$ 人 & $123034 \quad "$ & & $(9.9 \%)$ \\
\hline $10 \sim 19$ 人 & $211271 \quad$ " & & $(17.0 \%)$ \\
\hline $20 \sim 299$ 人 & 715836 & & $(57.6 \%)$ \\
\hline 300 人以上 & $95693 \quad$ & & $(7.7 \%)$ \\
\hline
\end{tabular}

出所：通商産業省生活産業局

表 2 都府県別規模別事業所数

\begin{tabular}{|c|c|c|c|c|c|c|c|c|}
\hline \multirow[b]{2}{*}{ 番号 } & \multirow{2}{*}{\multicolumn{2}{|c|}{\begin{tabular}{|l} 
都 \\
規模別 \\
道府
\end{tabular}}} & \multirow{2}{*}{\multicolumn{2}{|c|}{$\begin{array}{l}\text { 総事業 } \\
\text { 所 数 }\end{array}$}} & \multirow[b]{2}{*}{ 小 計 } & \multicolumn{3}{|c|}{ 事業所規模（19人以下） } \\
\hline & & & & & & $\begin{array}{c}5 \\
\text { 人 }\end{array}$ & $\begin{array}{l}6 \text { 人 } \\
9 \text { 人 }\end{array}$ & $\begin{array}{l}10 \text { 人 } \\
19\end{array}$ \\
\hline 1 & & 京 & & 246 & 4925 & 2960 & 1269 & 696 \\
\hline 2 & 茨 & 城 & & 703 & 590 & 335 & 144 & 111 \\
\hline 3 & 栃 & 木 & & 290 & 1168 & 707 & 304 & 157 \\
\hline 4 & 群 & 馬 & & 389 & 1263 & 743 & 319 & 201 \\
\hline 5 & 埼 & 玉 & & 003 & 1807 & 1060 & 455 & 292 \\
\hline 6 & 神艾 & 梷川 & & 919 & 870 & 547 & 235 & 88 \\
\hline 7 & 新 & 潟 & & 524 & 435 & 249 & 107 & 79 \\
\hline 8 & 富 & 山 & & 134 & 116 & 61 & 27 & 28 \\
\hline 9 & 石 & 川 & & 294 & 237 & 136 & 59 & 42 \\
\hline 10 & 福 & 井 & & 191 & 156 & 81 & 35 & 40 \\
\hline 11 & 愛 & 知 & 21 & 101 & 1932 & 1166 & 500 & 266 \\
\hline 12 & 岐 & 阜 & & 676 & 2498 & 1514 & 650 & 334 \\
\hline 13 & 京 & 都 & 12 & 293 & 1199 & 714 & 306 & 179 \\
\hline 14 & 太 & 阪 & & 860 & 3538 & 2128 & 913 & 497 \\
\hline 15 & 兵 & 庫 & & 970 & 831 & 441 & 190 & 200 \\
\hline 16 & 奈 & 良 & & 420 & 376 & 217 & 93 & 66 \\
\hline 17 & 和哥 & 次山 & & 409 & 351 & 187 & 81 & 83 \\
\hline 18 & 鳥 & 取 & & 113 & 63 & 21 & 9 & 33 \\
\hline 19 & 島 & 根 & & 108 & 49 & 18 & 9 & 22 \\
\hline 20 & 岡 & 山 & & 669 & 2349 & 1416 & 607 & 326 \\
\hline 21 & 広 & 島 & & 059 & 805 & 386 & 166 & 253 \\
\hline 22 & 徳 & 島 & & 260 & 175 & 66 & 29 & 80 \\
\hline 23 & 香 & 川 & & 416 & 266 & 118 & 51 & 97 \\
\hline 24 & 愛 & 媛 & & 365 & 273 & 129 & 56 & 88 \\
\hline 25 & 福 & 岡 & & 428 & 317 & 181 & 78 & 58 \\
\hline & & 計 & 298 & 846 & 26589 & 15581 & 6692 & 4316 \\
\hline
\end{tabular}

出所：通商産業省生活産業局 
一方，縫製品の需要構造は，近年既製服化が著しく， 背広服て昭 38 年で $38.8 \%$ \%゙あったのか昭 47 年では $50.1 \%$ ，女性スーツでは同 $22.4 \%$ 加 $62.4 \%$ 既 製服化率が急上昇している. 今後供給体制か整備されて てゆけば更に上昇する。また縫製品に関する赀好は急速 に高級化，多様化，個性化しており，消費者の要求に即 応できる体制を確立する必要があろう.

企業規模では従業員 20 人以下が全体の $85 \%$ ，その

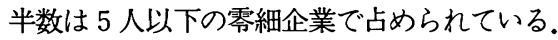

このような企業の零細性と過多性は近代化投資を困難 にし，更に過当競争のため収益性の向上か妨げられてい る.一般に賃加工形態をとっており, 多くは経営の非自 主性, 不安定性か強く, 近代的経営形態への移行が不徹 底である。

以上のように, 国際環境の変化, 労働力事情の変化, 需要動向の変化等に対応するために, 縫製業は情報収集, 商品開発，生産および商品流通の各機能を強化確立した 知識集約化グループの育成, 零細企業に対するグループ 化と技術指導, 生産合理化, 取引条件の改善に努める必 要がある。

\section{2. 技術上の問題点}

これまでに述べたように，内外に多くの問題を抱えて いるが, 今後縫製業が安定的な発展をはかるには如何に あったらよいか。

初めに 8 項目に分けて技術上の問題点を洗ってみて， つぎに技術開発のための方策を述べる。

これまでの技術開発の特徴はミシンメーカ先導的で あるところから, 高速化, 省力化等機械設備の開発に重 点があった。これからは生地から製品に至るまでの一貫 したシステム アプローチ，すなわちソフト面の技術開 発がハード面と同時平行的に進むことか望まれる。

また縫製業は婦人子供服などの極めてファッショナブ ルで多種少量生産型分野と, ドレス シャツなどに代表 される大量生産型分野に大別されこれによって生産形 態に構造的特徵をもたらしている実態から，二極分化的 傾向に対応したそれぞれの技術配慮が必要である。更に 縫製技能者不足への対応など技術面以外も含めた総合的 観点から対策を講ずる必要がある。しかし本文では縫製 業の知識集約型産業への誘導を困ることを前提として

○ソフト面における問題点, ○ ハード面の問題点 で緊急に技術開発を必要とする課題について述べる。

2.1 紳士服 - 婦人子供服・布帛縫製等個別業種内に おける技術上の問題点
他産業に比べて圧倒的にマテリアル ハンドリング作 業が多く，最終製品の需要動向の影響を直接被ることに なるため多様化に応じられることが重要であり, 縫製工 程全般にわたり生産技術面，管理技術面ともに合理化が 遅れている。

a. 工程管理上の問題点

受注生産が一般的であり，工程管理のねらいは納期問 題の解決に絞られる. 縫製工程の生産性は他業種と異な $\eta$, 機械の稼動率よりも作業員の作業能率が大きな比重 を占めている。一方今後は作業員の仲間との連帯, 自主 的な参画，すなわち人間疎外からの脱皮も重要な課題と なろう。また工程ラインのバランス状態を的確に予想で きる技術が不可欠となる。

縫製工程を編成していくために考慮すべき事項は，第 一にいかなる品種をつくるか, 生産ロット数は, 作業方 法をどうするか，を決定し，ついで作業人員，作業面積， 保有機器の順序組立てを行ない，工程分析，標準作業時 間の設定をなし，各工程にどのくらい仕掛りがたまり， 作業者の作業負荷がどのくらいになるかを知って工程編 成にフィードバックし，適正な工程の組合せを行なう。

縫製工場は，各作業者に同じように仕事量を配分する シンクロ システムより，一定の仕掛り品を工程ごとに ため，一定枚数を束ねて流す方式のバンドル システム を採用する例が多い. 今後は工程中へ高価な自動機を編 入した工程編成の合理的運用を考えてゆく課題も多くな ろう.

b. 技術上の問題点について

ミシン 1 台当りの平均稼動率は $20 \%$ 以下で, 紳士服 上衣のように工程数が多くなるほど低下する。ミシン作 業には，機械操作前後に布を取扱う手動作が多いためで ある。この時間の短縮のための技術が生産性向上のポイ ントになっている，その解決策として，(1)機械操作中に おける繊細な手動作の機械化，(2)製品の品質に大きな影 響を与えるパーツのワーク ポイントへのセットのみは 手動作に残しても, あとは手放しで1サイクルの工程 が終了できるようなミシン操作前後のマテリアルハン トリングの自動化, (3) (2), (3)の作業を合併したミシ ンの開発，(4)工程間を継ぐ無人化指向のマテリアル八 ンドリング機器モジュールの開発，その他，欠勤者対策 技術，熟練度の平準化などの技術開発が必要であり，さ らに工場規模や生産品種によって各様であるので, 人間 機械系としてのシステム技術の開発が重要である.

\section{2 今後の縫製における生産方式}

世界のアパレルの総消費量は年間約 2,400 万トンと 
推定され，1 人当り重量は約 $6.7 \mathrm{~kg}$ である. 日本では 1973年において $16 \mathrm{~kg}$ ，米国では $26 \mathrm{~kg}$ と推定される. このような消費水準からみると, 更に需要の增大か期待 できるが，国際的視野から今後の我国の縫製技術開発の あり方を考えると, 肌着等は発展途上国人技術移転し, 高付加価值化，技術集約化、指向することが道であり， 多様化へ対応できる生産方式となろう。

今日, 生産者は生活必需品としてのマス フアッショ ン的大量生産のなかで, 衣料本来の機能のほかに装飾的 な目的を加えるなど，多様化が一層顕著になってきてい る.ファッション衣料では市場情報の動向により, 少口 ット生産で追ってゆく方法がとられている。

多品種少量生産体制への移行に伴い，品種や仕様の変 更が激しく, 切換之時の生産問題を含め, 生産効率の低 下が大きな問題である.

縫製業における現状の生産方式をまとめると

a ) 個別生産方式

一名テーラード システムといわれ，1 人または数人 のものが全加工を担当する方式で人数も 3 10人，ロッ 卜枚数 30 〜 200 で多品種少量生産向きである.

b ）ロット生産方式

バンドル システムといわれ，1ロットごとに順次工 程に流す方式で, 米国で多く発展した方式で, 口ット枚 数も 1000 ～ 10000 で少品種多量生産向きで, 人数 も $100 \sim 200$ 人, 定常時, ロット切換時ともに生産性が 高い

c) 流れ方式

シンクロ システムといわれ，時間的に調和をとって 流す方式で, ロット枚数は $700 \sim 5000$, 人員は20 50 人，少品種多量生産向きであるが，口ット切換時に 生産性が非常に低下寸る欠点がある。

b ）自動化生産方式

自動的に操作される機械加工方式で, ドレス シャツ 工程で最も進んでおり, 数工程を同時加工する複合ミシ ン, トランスファ マシン型, N C シシン, マテリアル ハンドリング作業をミシン作業に結合した型，工程間結 合のパーツ縫製のマテリアル ハンドリング機械等が従 来の生産ラインに取り込まれている.今後の開発が期待 される。

一般的には多品種少量生産体制への移行に伴い, 品種 や仕様の変更が激しく, ロット切換時の生産問題を含め, 生産効率の低下が大きな問題である。これらの問題解決 には，類似の品種に生産を絞り，固定部分と変更部分と に分離可能な点を明らかにして，固定部分は定常化，専
門化を図り，変動部分は徹底した管理手続を適用する対 策を講ずることである．作業者には類似の工程や同性質 の工程を配分するよう心掛ける必要がある。近年この考 え方に立った生産方式が発展し，縫製工程にも取り入 れられている.その1つは，グループ テクノロジの考 え方であり，類似したもの（形状，寸法等の類似性や工 程系路, 加工方法, 取付方法の加工技術類似性) をグル 一プにまとめ，その類似性に着目して，同一の取り扱い (工程編成，ロット構成上 等) を系統的に実施するこ とにより多品種少量生産性を向上する。これは部品の加 工技術的類似性に基づいて，部品をグループ化すること から出発したものであるが, 最近では, 作業の多様化と 作業者の自由度の尊重を建前として, 流れ作業方式にお けるベルト コンベアの強制から作業者を解放し，作業 者に生き甲斐を与え，定着率を高めることを目標にした グループ プロダクション方式が欧米各国で大きな関心 を集めているが，これは作業者のグループがある定めら れた範囲の部品の生産や組立作業などを責任をもって遂 行する方式である. 表 3 はグループ プロダクションと グループ テクノロジの比較である.

表 3 部品加工における G P と G Tの比較

\begin{tabular}{|c|c|c|c|c|c|}
\hline & グ ル -70 & 化 の 順 序 & 効 & & 果 \\
\hline \multirow{2}{*}{ GP } & \multirow{2}{*}{ 作業者グループ } & 部品 グループ & \multirow{2}{*}{$\begin{array}{l}\text { 人間性 } \\
\text { 尊 重 }\end{array}$} & \multirow{2}{*}{$\rightarrow$} & \multirow{2}{*}{$\begin{array}{l}\text { 生産性 } \\
\text { 向 上 }\end{array}$} \\
\hline & & 加工機械グループ & & & \\
\hline \multirow{2}{*}{ GT } & \multirow{2}{*}{ 部品グループ $\rightarrow$} & 作業者 グループ & \multirow{2}{*}{$\begin{array}{l}\text { 生産性 } \\
\text { 向 上 }\end{array}$} & \multirow{2}{*}{$\rightarrow$} & \multirow{2}{*}{$\begin{array}{l}\text { 人間性 } \\
\text { 尊 重 }\end{array}$} \\
\hline & & 加工機械グループ & & & \\
\hline
\end{tabular}

縫製工程でも，作業者の数人ずつを適当なグループに まとめ, 各単位ごとに時間的なバランスをとり, 各品種 に対し効果的な分業が行なわれはじめている.

設備配置は，一般に工程別と機種別に分けられるが， 機種別配置は工程間の製品移送に欠点が生ずるが，生産 工程か湾ってもその配置を変えずにすむので多品種生産 向きである。いずれにしろ多品種少量生産では作業者に 適当な数量の仕掛りを持たせる「ロット生産方式」を採 らざるをえないから，その切換え口スを如何に省くかが ポイントとなり, 今後生産管理にコンピュータの導入が 望ましくなろう。

\section{3 生産から販売までの情報管理システム}

縫製業で情報の管理システムを考えるとき，二つの観 点がある。一つは，多様な要因をもつマーケット情報を 
システム的に予見し，きたるべきシーズンの商品企画を 的確ならしめようとする「予測情報の管理」と，いま一 つは, 企画が決定された後での, 原材料 $\rightarrow$ 生産 (裁断, 縫製，仕上，包装） $\rightarrow$ 在庫 (工場在庫, 営業在庫) $\rightarrow$ 販 売 (出荷) に至る進行情報を敏速に把握して, 生産およ び販売上の機会損夫を最小にする「確認情報の管理」で ある，縫製業の現段階では，まず後者の「確認情報の管 理」をシステム的に行なえるレべルまでもってくること が先決で，しかる後「予測情報の管理」へとトータル システム化すべきである.

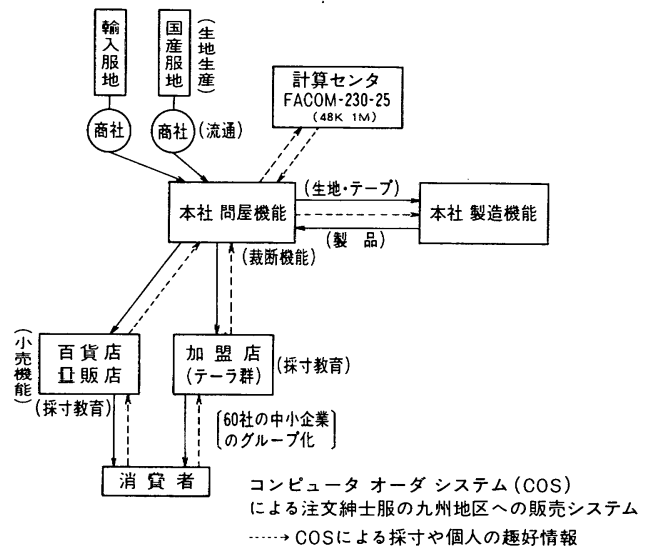

図 1 九州における垂直化自動化システムの例

最近，大手商社が中心となって，(機能の)垂直化(生 産・情報処理の) 自動化システムが九州諫早を拠点とし て運用されはじめた。図1はその構成を示したものであ るが, これは, 問屋・裁断機能をもつ本社に直に計算七 ンタ, 縫製品製造機能が連なり, これに生地の生産流通 を受持つ商社か冠さり，小売機能をもつ百貨店，量販店， テーラ群がぶらさがって消費者に直結し, 注文神士服 の生産・販売システムを構成している.

以下情報管理の高度なシステム アプローチに際して 起りうる問題点をあげると

a ) 材料の所要量と裁断枚数の割り出し手間の解決 (コンピュータ マーキング グレーディングの採用)

b ) 単位作業の進捗状況の ばらつき解決（クーポン チケットの発行とこれの機械読取機の導入)

c ）広域に広がった工場での生産進度情報の即時集約 化（コンピュータ ネット ワーク）

d）衣料製品の特性に応じた倉庫管理方法の開発（流 通セン夕設置)

e ）取引先との相互理解を深め, 自社システムの有効 な活用を困る（自社コンピュータ システムの活用）
などである.

2.4 ファッション化への対応と新生産システム

生産水準の高度化，若年層の購買動機の増大，レジャ スポーツ等に付隨する高年令層のファッション化の傾向 からみて，需要はますます増加する。高級品ではファッ ション要素がきわめて強く，その対策としてはマーケッ トの動向を常時把握できるための機能の消費地への立地， 市場情報機能の強化を図り,ファッション化の傾向を追求し, その製品化を図るためのデザイナの養成，縫製技術の 向上，試作品のプリテストなどの開発体制の強化が必要 である。

ファッション性の最もはげしい高級ニット婦人服分野 に例をとると，年間 6 シーズンから 8 シーズンのライフ サイクルで販売展開が行なわれ，展示発表会前における 1 型見本は 3 日〜 5 日で製作され，内見検討会が行なわ れ，展示発表会には 1 スタイル5色前後出品され，その 縫製日程は 5 日〜 7 日間，受注決定後，20日〜 22 日 が縫製生産サイクルとして本番生産が行なわれる。ささ に基準サイズからレギュラサイズ，ハーフ サイズ等の 展開が行なわれ，1スタイルにおける生産ロットは 200 着〜 300 着前後がほとんどである. 図 2 は年間 30 万

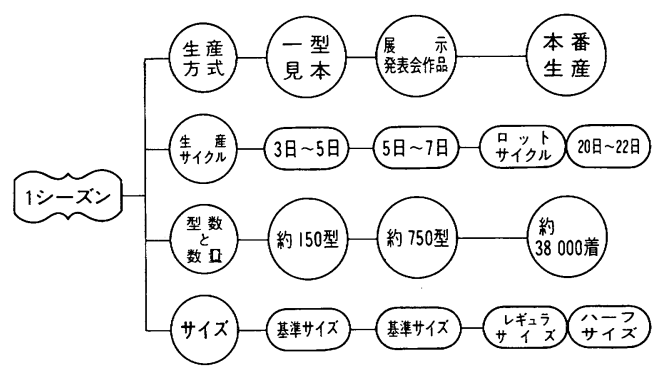

図2 多品種小ロット生産例

着を生産している高級ニット婦人服縫製の年 8 シーズン における 1 シーズンの型見本から本番生産までの，既製 服分野での，多品種小ロット生産の一例である．以上の プロセスからも推測できるように，現代のファッション

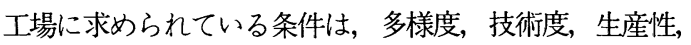
迅速性であり，これを基本的に満す技術条件は迅速で正 確な裁断にあるといえる。この条件に合う自動裁断機で はレーザ光利用や流体ジェット法などがこれからの問題 として考えられる.四3は流体ジェット裁断機の構成で あるが我乃の実験では $4200 \mathrm{~kg} / \mathrm{cm}^{2}$ 圧でドレス シャツ 100 枚が $30 \mathrm{~m} / \mathrm{min}$ で厚さ方向に寸法正確に裁断でき, その他使用上の利点が多いので，これからに期待できよ う。また，今後は省資源等の立場から「ファッション性」 


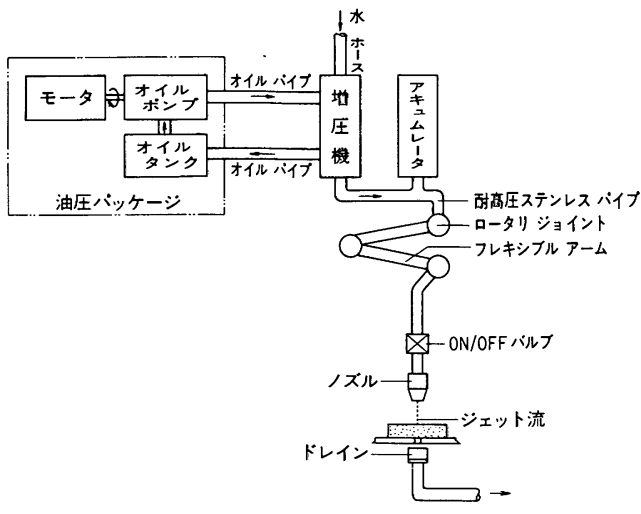

図 3 流体ジェット裁断機

と「丈夫で永もちする実用性・個性化」の相矛盾する要 求の調和の技術も必要となろう。

\section{5 製品の品質性能の向上に対する方策}

縫製品の品質については, 設計の品質, 性能的品質お よび製造上の品質に分けられる。

設計による品質とは縫いが丁寧か, ボタン付けがし っかりしているかなどの実用的要素, 着やす巳, 型くず れがしないかなどの機能的要素，および主材料，副材料 の選択などの性能的要素を総合的に調査し，消費者の要 求を製品に反映させる企画・設計である。実際には縫製 の粗雑さ, 品質の不均一, 工場指図の不徹底があり, そ の解決には作業標準の確立，品質規準の作成，加工指図 の徹底，協力工場の技術水準の向上が必要である．機能 性や消費者嗜好を満すためには，内外技術との提携，企 業の創造性，情報収集のシステム化等があげられる。

性能的品質とは一次的性能として引張り強さ，収縮率， 染色堅牢度などがあげられ，適当な試験，検相機関を利 用して要求性能をチェックする。二次的性能としては洗 濯時の外観変化，パッカリング等，また縫い系や縫い代 等の検查を試作段階で行う他，品質表示の適正化を進め ることが必要である。

製造の品質とは製品が規格通りに，指図どおりに作ら れているかであり，そのためには現物管理のための管理 体制と検查制度の強化が必要である。

\section{6 技術開発と労㗢力不足}

今後縫製業は高度商品分野への品種転換が指向される ので，労働力の質的低下を補うにも生産技術面，縫製技 術水準の向上か極めて重要な課題である。

ファッション性に起因する個性化，多様化と一定の生 産力を維持するための規格化，標準化という矛盾した命 題のなかて調和のとれた技術開発が基本的課題である.
具体的には素材やべースとなる工程の段階でのモジュー ル生産技術の適用と最終加工組立段階て個性化，多様化， を図るというシステム技術の開発による解決の方向が指 向されよう。

\section{7 縫製品製造業における技能・技術者育成の重要} 性

我国縫製業における技術教育は，工場内で必要に応じ た技術・技能の修得が中心となっている，今後縫製業が アパレル産業として近代化への脱皮を果すためには米国 F I Tにみられるごとく，ファッションに関連するデザ イン マネージメント，マーチャンダイジング，エンジ ニャリング等の専門分野における人材育成と広い視野か らの教育が必要である。

\section{8 共同生産体制への誘導と技術開発}

過去における合併および協業等による企業の集約化は 主としてスケールメリットの追求を目指したものであ ったが，零細企業者一般の企業家意識にはなじめなかっ た.

零細企業については当面，事業協同組合等を設け，倉 庫，仕上げ，ならびに裁断部門等の施設の共同化を進め, これに対し設備資金の融資を行ない，知識集約化の育成 指導をする必要がある。

一方，近代設備を十分活用するための技術や経営能力 のレベル アップが必要である.このため，(1)小ロット 生産の効率を向上させる生産技術，経営技術の開発，(2) 設備近代化およびこれを利用する技術の開発を計画的に 推進する, (3)スケールメリットの追求可能な品種, 工 程については革新的設備の開発に努めること等の方策を 早急にとることであろう。

\section{3. 開発課題とその必要性}

表 4 に挙げた技術開発課題の選定にあたっては，中小 企業振興事業団の「技術開発課題報告書・昭 48 年度」 を参考とし，更に緊急を要するもの，長期的に重要度の 高いものを考慮して，多くの課題中から特に重要な 10 テーマにまとめた (次ぺージ参照).

\section{4. 技術開発のための方策}

\section{1 ソフト技術開発主体について}

労働集約産業からシステム産業に脱皮するためには, 省力効果の大きいハード技術の開発はもちろんであるが， それぞれ異った生産環境をもつ縫製業に適応するシステ ム運用のためのソフト技術の開発が重要であり，中小企 業振興事業団，国公立研究機関等か核となって官民より 
表 4 縫製業における技術開発課題とその開発の方向

\begin{tabular}{|c|c|c|}
\hline 技行 & 内 & 方 \\
\hline $\begin{array}{l}\text { (1)生地の安定化の研 } \\
\text { 究 }\end{array}$ & $\begin{array}{l}\text { (1)柄流れ, Uずみ等のない生地を生産するための紡績, } \\
\text { 製布, 染色整理技術を向上させるための研究 } \\
\text { (2)生地の残留ひずみを取り除く前処理用生地セッタの開 } \\
\text { 発. 素材別に縮繊可能な縮繊機 }\end{array}$ & $\begin{array}{l}\text { 綎製工業における品質水準や許容量の基準を } \\
\text { 設定するとともに, 素材メーカとの共同研究 } \\
\text { による開発 }\end{array}$ \\
\hline $\begin{array}{l}\text { (2)検反機および検反 } \\
\text { システムの開発 }\end{array}$ & $\begin{array}{l}\text { 各種の疵の検出法, チェック法を研究し, これらの機能 } \\
\text { をもった自動的検反機を開発するとともに効率的な検反 } \\
\text { システムの開発 }\end{array}$ & $\begin{array}{l}\text { 繾製業における品質水準や, 許容量の基準を } \\
\text { 設定するとともに素材メーカと機械メーカ等 } \\
\text { の協調による開発 }\end{array}$ \\
\hline $\begin{array}{l}\text { (3)プロファイル シ } \\
\text { ヨート シーマの } \\
\text { 開発 }\end{array}$ & $\begin{array}{l}\text { カウンタ シーマ的な条件で, マイクロ コンピュータの } \\
\text { 導入等によク, パターンの変更に容易に応じられる小物 } \\
\text { パーツの自動機の開発 }\end{array}$ & $\begin{array}{l}\text { 䋖製メーカとの共同研究による機械メーカの } \\
\text { 開発に期待 }\end{array}$ \\
\hline $\begin{array}{l}\text { (4)完全自動サージン } \\
\text { グ機械の開発 }\end{array}$ & $\begin{array}{l}\text { 縫い距離の長いスラックスなどの身頃のほつれ止めを三 } \\
\text { 方向連続してできる自動機の開発 }\end{array}$ & $\begin{array}{l}\text { 縫製メーカの協力を得ながら主としてミシン } \\
\text { メーカによる開発 }\end{array}$ \\
\hline $\begin{array}{l}\text { (5)紳士服, 婦人服用 } \\
\text { 袖付けミシンの開 } \\
\text { 発 }\end{array}$ & $\begin{array}{l}\text { 現在の袖付けミシンは, いせ込み加減に熟練を要するた } \\
\text { め, 主としていせ込み加減の制御方式の研究開発. 袖付 } \\
\text { 加工は, 技術・生産両面から险路工程, 非熟練化 }\end{array}$ & $\begin{array}{l}\text { いせ込みの制御の研究が必要となるので国公 } \\
\text { 立試験研究機関, ミシンメーカ,および縫 } \\
\text { 製メーカとの緊密な協力による研究が必要 }\end{array}$ \\
\hline $\begin{aligned} \text { 66自動裁ち目揃之装 } \\
\text { 置付きミシンの開発 }\end{aligned}$ & $\begin{array}{l}2 \text { 枚の生地の裁ち目を自動的に揃える装置付き上下送り } \\
\text { または差動送りミシンの開発. 前作業の解決策 }\end{array}$ & $\begin{array}{l}\text { ミシン メーカと縫製メーカとの共同研究に } \\
\text { よる開発 }\end{array}$ \\
\hline $\begin{array}{l}\text { (7)工程間搬送システ } \\
\text { ムの開発 }\end{array}$ & $\begin{array}{l}\text { (1)工程間搬送におけるマテハンの諸動作研究及び装置の } \\
\text { 研究 } \\
\text { (2)手作業の組合せとしてのシステム設計研究. 工程間搬 } \\
\text { 送は全作業の } 40 \% に 及 ふ ゙ \text { 無人化のポイント }\end{array}$ & $\begin{array}{l}\text { ハンガ方式との区分けの問題と布の形状, 物 } \\
\text { 性値によるハンドリング特性の把握を要し, } \\
\text { 国公立試験研究機関, 機器メーカおよび縫製 } \\
\text { メーカとの総合開発 }\end{array}$ \\
\hline $\begin{array}{l}\text { (8)パーツ縫製のマテ } \\
\text { ハンン自動化の研究 }\end{array}$ & 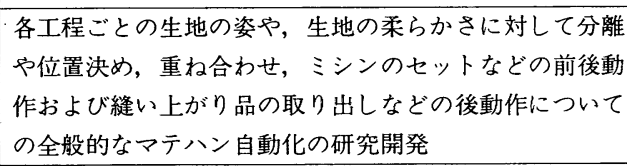 & $\begin{array}{l}\text { 䋖製メーカと国立試験研究機関および機械メ } \\
\text { 一カとの協調による開発 }\end{array}$ \\
\hline $\begin{array}{l}\text { (9)縫製工場向きの機 } \\
\text { 能をもった倉庫と } \\
\text { 搬入方法の研究 } \\
\text { (原材料倉庫) } \\
\text { (商品倉庫) }\end{array}$ & $\begin{array}{l}\text { (1)ロール状原反の形状に適した貯反方法の研究および設 } \\
\text { 備開発 } \\
\text { (2)適正在庫量の設定 } \\
\text { (3)製品（商品）の保管研究とその設備開発 } \\
\text { (4)原反及び製品の搬入方法の研究 } \\
\text { (5)以上のモデル システムを開発する }\end{array}$ & $\begin{array}{l}\text { 自動倉庫メーカ, 自動搬送機器メーカと縫製 } \\
\text { メーカ, 国公立試験研究機関との相互協力に } \\
\text { よる開発 }\end{array}$ \\
\hline (10接着用樹脂の開発 & $\begin{array}{l}\text { 点接着での即乾, 接着面のフレキシビリテイ等の条件を } \\
\text { 満たし, 常温短時間接着および透明度が高く接着強度の } \\
\text { 高い樹脂の開発 }\end{array}$ & $\begin{array}{l}\text { 国公立試験研究機関および樹脂メーカと縫製 } \\
\text { メーカとの協調による開発 }\end{array}$ \\
\hline
\end{tabular}

なる頭脳集団を作り, 関係業界と相互協力によって開発 するのが適切である。

昭 49 年度から向う 3 年間の計画で「生産工程モデル システム」の開発を国家事業として行っており，49 年 度は縫製業に使用される裁断機器，縫製機器，情報処理 機器の調査，整理を行なってきた。

4.2 主としてミシンメーカ等による開発

(1) プロファイル ショート シーマの開発

(2) 紳士服，婦人服用袖付けミシンの開発

（3）完全自動サージング機の開発

(4) バンドループ自動縫着機の開発

更に機械メ一カ, 国公立研究機関との協力により開発が 期待されるものとして
(1) パーツ縫製のマテハン自動化の研究

(2) 工程間搬送システムの開発

(3) 無人縫製システムの開発 これらの開発に当っては，かなりのリスクが予想される が，国においても現行の技術改善費補助金，国産新技術 企業化等，融資制度のほか，中小企業振興事業団の技術 開発事業および機械振興協会の新機械普及促進事業等の 積極的な活用を図ることが必要である。

国家事業としては，中小企業振興事業団が母体となっ て, 昭 50 年度より向う 4 か年間の特別研究開発事業と して「パーツ縫製のマテハン システム化技術」の研究 開発を行なう。本研究開発は，紳士服，婦人服，ドレス シャツ等の縫製工程のなかで，特に人手を使っている身 
頃，衿，袖等のマテハン自動化を行ない，システム化を 図ろうとするものである.

\section{3 主として国公立研究機関による開発}

(1) 生地の安定化の研究

(2) 検反機および検反システムの開発

（3）縫製工場向き機能をもった倉庫と搬送方法の研 究

(4) 接着用樹脂の開発

\section{4 縫製業界が技術開発に果す役割}

ここに選定した技術開発課題は縫製業界の技術開発二
一ズを集約したもので，当該業界の現場的ノウ八ウの 蓄積か開発成功の鍵を握っているのであるから業界の主 体的努力か極めて重要である.ささらに新製品, 新規デザ インの開発等，技術開発上に果す役割の大きいことを強 く認識しなければならない。

最後に，本報文は中小企業近代化審議会技術開発部会 縫製分科会か昭 49 年 4 月にまとめた「縫製品製造業に おける技術開発のあり方に関する報告」の概要を骨子と して，私見を一部混えて作成したものである。

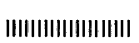

評

\title{
「縫製機器総合カタログ」
}

\author{
松下工業株式会社 \\ 取締役社長 松下良一 編集発行 \\ $\left(\begin{array}{l}1974 \text { 年 } 6 \text { 月刊，本文 } 680 \text { ページ，資料40ペー济 } \\ \text { 定価 } 6000 \text { 円，送料 } 200 \text { 円 }\end{array}\right)$
}

元来, わが国の縫製業は零細企業が多く，そのため設 備の近代化も他の繊維加工業にくらべ，はるかにおくれ ているのが実体であった。しかしここ数年間に，この縫 製業の後進性をとりもどし，体質を改善し，近代企業化 をはかろうというムードが急速に高まってきた。

折しも新構造改善法案が決まり，このムードに一層拍 車がかけられるようになった。

しかし体質を改善し，設備の近代化を計画しても縫製 機器の選定となると現実にはなかなかむずかしく，せい ぜい同業者の話の中から評判のよい機種を選ぶ, 特定 の機器メーカーの売込みに応ずるか, というのが実状で ある。われわれが本当に企業規模にマッチし，しかも手 がける製品に適した機種を選ぼうとするならば，このよ うな安易な方法ではなく, 自から各機種の性能, 特徴を 比較検討しなければならないことは論をまたない。

しかし残念ながら，従来縫製機器に関する図書は極め て少なく，とくに各社の機器を同一レベルに並べてその 性能，特徵を比較できるような便利なものは皆無であっ
た. 今回, 松下工業（株）から出版された「縫製機器総合 カタログ」はこのような業界のニーズに応えた図書と言 之，縫製業者のよき参考書として利用できるであろう。 ただし，内容について欲を言えば, 現在話題になって いるコンピューターグレーディング，マーキング システム，さらにオートクロスカッターなどの縫製 準備工程の近代化機器, またはN Cミシンなどが収録さ れていないのが物足りない.

また，ここまで多くの資料を集めることができたので あれば，単なる「カタログ集」から一歩進めて，客観的 な評価，その機器の適性などの論評を加えた「縫製機器 便覧」として改訂するならば一層業界にアピールするで あろう．最後にこの「カタログ集」には縫製に関する用 語集も収録されていることを付言しておこう。

\section{（東洋紡績 商品開発部 副部長 一見 輝彦)}

